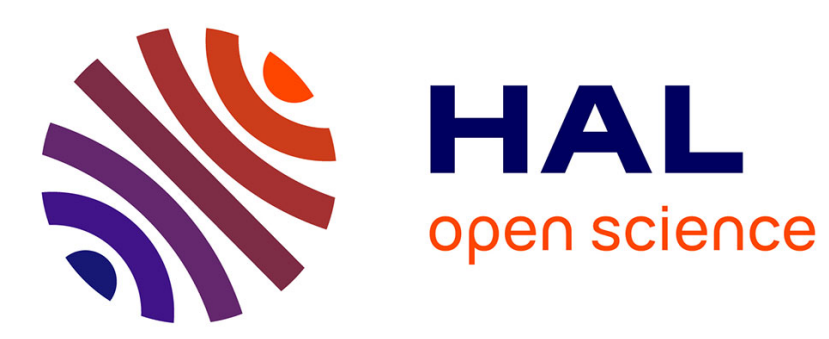

\title{
Comment helical textures in 3He-a in superflow and magnetic field
}

\author{
Y.R. Lin-Liu, K. Maki, D. Vollhardt
}

\section{To cite this version:}

Y.R. Lin-Liu, K. Maki, D. Vollhardt. Comment helical textures in 3He-a in superflow and magnetic field. Journal de Physique Lettres, 1978, 39 (23), pp.471-471. 10.1051/jphyslet:019780039023047100 . jpa-00231548

\section{HAL Id: jpa-00231548 https://hal.science/jpa-00231548}

Submitted on 1 Jan 1978

HAL is a multi-disciplinary open access archive for the deposit and dissemination of scientific research documents, whether they are published or not. The documents may come from teaching and research institutions in France or abroad, or from public or private research centers.
L'archive ouverte pluridisciplinaire HAL, est destinée au dépôt et à la diffusion de documents scientifiques de niveau recherche, publiés ou non, émanant des établissements d'enseignement et de recherche français ou étrangers, des laboratoires publics ou privés. 


\title{
COMMENT
}

\section{HELICAL TEXTURES IN ${ }^{3}$ He-A IN SUPERFLOW AND MAGNETIC FIELD}

\author{
Y. R. LIN-LIU, K. MAKI and D. VOLLHARDT
}

Department of Physics, University of Southern California, Los Angeles, California 90007, U.S.A.

J. Physique Lett. 39 (1978) L-381

1. - Outside the broken line in figure 1 , the stability of helical textures with $\beta \simeq \pi / 2$ and $\theta \simeq \pi / 2$ has been tested and we find that these helical textures are unstable.

2. - In the calculation of the NMR frequency, some errors are involved. A proper treatment of spin fluctuations yields two longitudinal modes with resonance frequencies

$$
\left(\omega_{1}\right)_{1,2}=\left(\lambda_{1} \Omega_{\mathrm{A}}^{2}+\frac{1}{4} \omega_{0}^{2}\right)^{1 / 2} \pm \frac{1}{2} \omega_{0}
$$

and two transverse modes

$\left(\omega_{\mathrm{t}}\right)_{1,2}=\left\{\left(\lambda_{1}+\left(\frac{1}{2} \pm 1\right) k^{2}\right) \Omega_{\mathrm{A}}^{2}+\frac{1}{4} \omega_{0}^{2}\right\}^{1 / 2} \pm \frac{1}{2} \omega_{0}$ where $\lambda_{1}$ has already been given in the letter and $\omega_{0}$ is the Larmor frequency. The above results should replace the incorrect statement on the NMR frequencies in the letter. Only in the limit $\omega_{0}, k \rightarrow 0$, do we recover our earlier result. The details of the derivation will be published elsewhere.

We would like to thank Pr. W. M. Saslow for his very constructive criticism of our paper. 